\title{
Collaborative Strategies \\ for Re-Enhancing Hapū Connections \\ to Lands and Making Changes \\ with Our Climate
}

Huhana Smith

\begin{abstract}
$\mathrm{T}_{\mathrm{h}}$ his article highlights critical Māori agency, which has enhanced intergenerational connections to, and responsibilities for, coastal landholdings in Māori land tenure, including the work of hapū (collectives of families) to harness their creative capacities to retain, transform, and (re)create ways of life in their interactions with human and other-than-human entities. This article offers some insight into culturally grounded, transformative, and action-orientated environmental and climate change research projects. These have been undertaken incrementally over the last twenty-two years within a Māori coastal case study between the Hōkio and Waitohu Streams, located from the southwestern Horowhenua to Kāpiti regions of Te Ika a Maui/North Island, Aotearoa New Zealand.

Positive ecological transformation and revitalization has taken place within these coastal lands, which have been largely managed by related hapū and alongside neighboring but unrelated hapū. Since I996, across this region (map I), hapū and external specialists have been working closely together to address the impacts of fragmented ecosystems on freshwater sources, human health, and biodiversity. My role was to support hapu as they expressed their initial concerns and then convene additional environmental specialists to assist us over the years. Further contextual issues surrounding Indigenous and Pacific human relationships to fresh waterways have been well highlighted by esteemed scholars and environmental activists such as Dame Anne Salmond (2OI4), Toon van Meijl (2015), and contributors to a volume edited by John Wagner and Jerry Jacka (20I8) and feature within Christine Winter's doctoral thesis (20I7),
\end{abstract}

The Contemporary Pacific, Volume 32, Number I, $21-46$

(C) 2020 by University of Hawai' $i$ Press 
which focuses on the interdependencies and entanglements between the human and other-than-human through the lens of intergenerational environmental justice.

In recent years, our team's critical research attention has turned to a revered ancestral coastline's related climate change vulnerabilities. Pictured in map I, this area was once renowned for its extensive coastal forest and its dune lakes, lagoons, and wetlands within iwi (collective of hapū) regions that were guarded by the neighboring hapū of Muaūpoko at Hōkio; the wider hapū of Ngāti Raukawa ki te Tonga at Waiwiri, Muhunoa; Ngāti Tukorehe at Kuku; Ngāti Wehiwehi at Waikawa; and Ngā Hapu o Ôtaki at Waitohu. From the turn of the twentieth century and after World War I, the region of Horowhenua was subjected to extensive draining of wetlands and felling and clearing of coastal lowland forests to make way for pastural farming.

Even though today the coastline remains predominately in Māori land title, over the last forty years the effects of intensified dairying, coastal dune pine tree forestry, and expanding inland market gardens have resulted in accumulated impacts on the health of freshwater springs and tributaries that then join major waterways flowing into the sea. Vehicle access has added to the degradation of sensitive coastal dunes at Kuku Ōhau and Waikawa estuaries (figure I), causing concern for rare coastal plants, shorebirds, and shellfish biodiversity.

This article contextualizes how agricultural modification has affected our cultural survival as hapu and highlights how Treaty of Waitangi claims leverage research through the Waitangi Tribunal as they seek redress to the adverse actions of Crown agencies. This contemporary redress aims to uphold our guarantee of maintaining rangatiratanga (leadership, authority, and determination of futures) as hapū and iwi over our waterways and lands. Such promises were enshrined in the Treaty of Waitangi in I 840. Despite the context of these historic Crown failures and their enduring legacies, treaty-claims research provides a strong basis for revaluing and prioritizing actions over our water bodies and associated freshwater resources that flow into the marine environment as contemporary acts of rangatiratanga and active kaitiakitanga (Māori environmental guardianship) (Potter and others 20I7).

Such leadership, guardianship, and protection were critical for the intensive experience of the "Manaaki Taha Moana: Enhancing Coastal Ecosystems for Iwi and Hapū" research project (see Manaaki Taha Moana 20I 5), a major government-funded project by the Ministry for Business, 


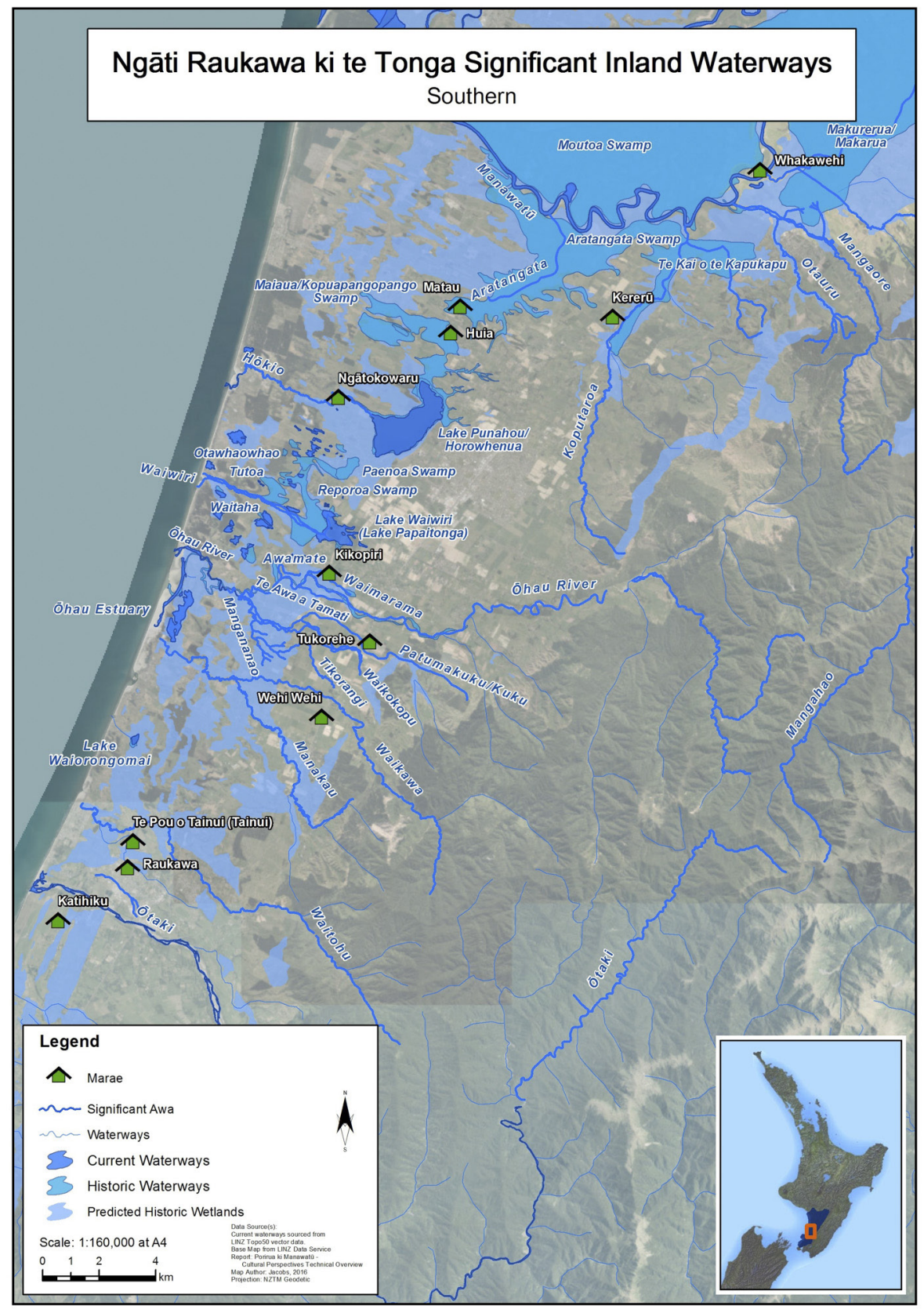

MAP I Overview of southern water bodies of significance to Ngāti Raukawa ki te Tonga, to which Ngāti Tukorehe is affiliated. From "Porirua ki Manawatū Inland Waterways Cultural Perspectives Technical Report" by Te Rangitāwhia Whakatupu Mātauranga Ltd (20I7), commissioned by Crown Forest Rental Trust, Wellington. Reproduced with permission. 


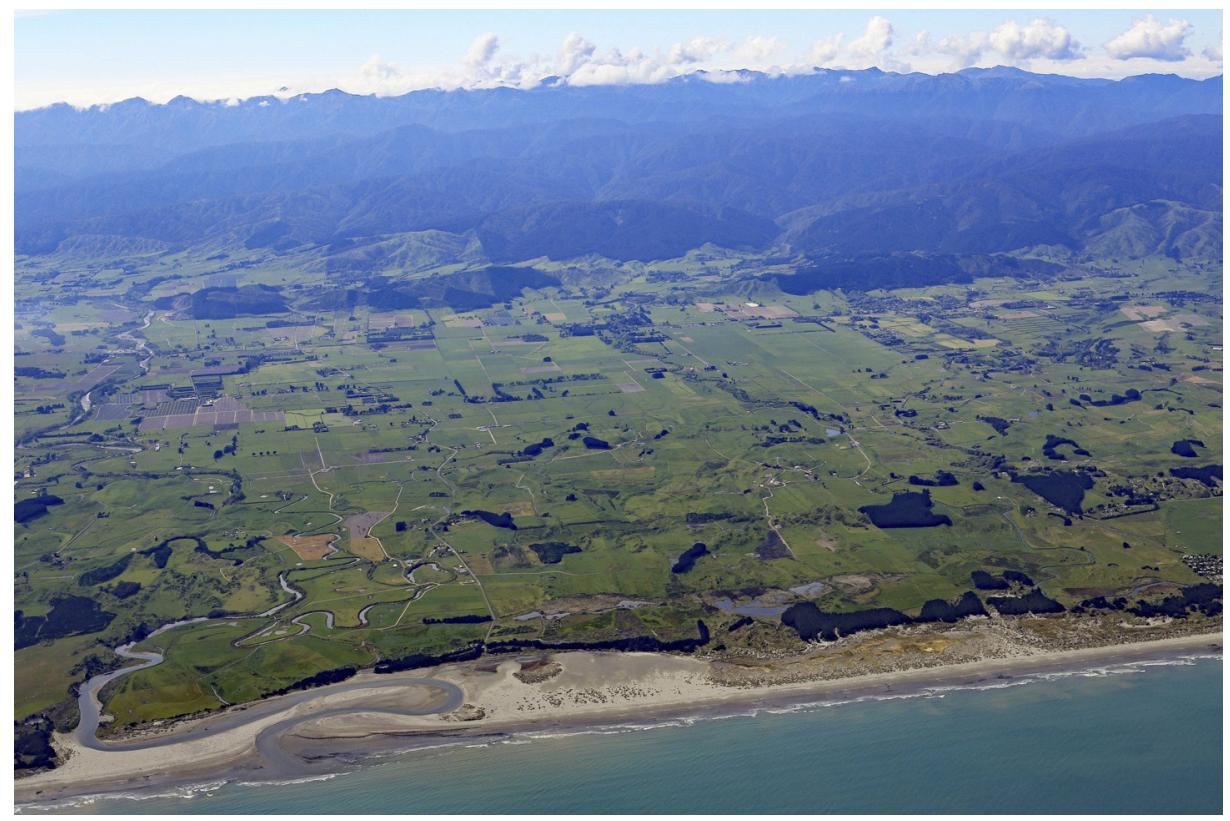

Figure I Mountains to sea featuring part of the coastal case study region-the Kuku Ōhau estuary and south toward the Waikawa River. Aerial photography by Lawrie Cairns, Palmerston North, 28 October 2017. Reproduced with permission.

Innovation and Employment from 2009 to 2015 . Importantly, this project was motivated by a sense that it was vital not only to assess ecological health baselines for the coastal freshwater systems from the uplands to the sea in this area but also to establish an interdisciplinary team of experts to collaborate toward shared project goals. The project was known simply as MTM, with a team that encapsulated the skills of Māori cultural experts, who then helped the range of specialists work within a Māori cultural context. The MTM team was made up of an archaeoseismologist, a coastal processes expert, terrestrial and coastal freshwater ecologists, a hydroecologist, ecological economists, landscape architects from the Victoria University of Wellington Faculty of Architecture and Design, and tidal marine scientists from Cawthron Institute in Nelson. For the more recent climate change projects, the group comprised local Māori researchers, artists, landscape architects, 2-D and 3-D designers, a fluvial geomorphologist, climate change scientist, and senior MA students.

The results of the climate change-framed collaboration called "Adap- 
tation Strategies for Climate Change for Coastal Māori Communities" (2015-2017) are overviewed briefly in this article. In addition to government support, this project was also funded as a Vision Mātauranga climate change project under the Deep South Te Kōmata o te Tonga National Science Challenge research program. Vision Mātauranga is now a well-recognized policy to ensure mātauranga Māori (Māori knowledge) and Māori research methods are acknowledged alongside scientific knowledges and research. The mission of Vision Mātauranga is "to unlock the innovation potential of Māori knowledge, resources and people to assist New Zealanders to create a better future" (Ministry of Research, Science and Technology 2007).

Aligned with this context, mātauranga Māori is regarded as an evolving system of knowledge development and underpins contemporary agency. Mātauranga Māori explains a Māori world as anchored by a whakapapa, or interconnected genealogies, framework, through which intricate kinship systems illuminate tangible and intangible relationships between tūpuna (ancestors), iwi, hapū, and whānau (families), lands, waterways, and the natural world. Such a framework supports inclusive Māori environmental values, which echo how whakapapa denotes a shared genealogy between humankind, spiritual entities, animals, and plants (see also Roberts and others 2004). This interconnectedness then extends to whānaungatanga, or kinship ties between people and environmental entities. This reiterates a deep sense of belonging and interrelatedness to place. Wairuatanga highlights the respect given to spiritual entities that exist within lands and waterways, especially where ancestral connections are evoked and acknowledged within an interconnected time/space continuum. Manaakitanga is the environmental value that protects and cares for resources for associated human sustenance and well-being. Rangatiratanga is closely aligned to mana whenua as authority over lands, with mana moana being the authority over waterways into the sea. Rangatiratanga recognizes how iwi and hapū authorities lead decision-making processes over these rohe (regions) (Smith 2007).

The MTM research team (now known as the Kei Uta Collective) cocreated new frameworks for short-term issues and long-term impacts of climate change and sea-level rise. The Kei Uta Collective readily built on the MTM experience and its well-used, trialed, and tested Māori research methods. Therefore, wānanga (intensive learning experiences), hui (meetings), and hīkoi (walking and talking meetings) remained key research methods and continued to help gather more Māori coastal communities 
together with a range of experts to explore the ecological and socioeconomic impacts of climate change.

For decades, climate change scientists and environmentalists across the world have been preoccupied with increased atmospheric carbon dioxide levels and associated climate change impacts. However, it has only been within the last decade that our Māori communities have become increasingly aware of how global warming and climatic changes are impacting our current coastal land use economies. For instance, unpredictable climatic extremes are currently making "business as usual" land use via dairying more vulnerable and this vulnerability more visible to local farmers and their communities.

Since 1996, all our local efforts have been based on the sensibilities of kaumatua (elders) and Māori healers, many of whom are now no longer with us. They instilled a sense of obligation and responsibility in us as the next generations to acknowledge the relationships that exist between humanity and the environment for everyone's health and well-being. They encouraged us to know our locale, our place of standing within it (Smith 2007), and to recognize the unique environmental and spiritual values that support future generations' cultural, physical, and economic welfare.

In further developing our methodological kete, or toolkit, the Kei Uta Collective used exhibitions as methods for research and as ways of both gathering and disseminating knowledge. (For another example of exhibitions' role in disseminating knowledge, see Mel, this issue.) We translated consolidated geological and cultural data from climate change research projects into university-based exhibitions, combining design, scientific data and models, and art elements to share these complex findings and explore new perspectives and possibilities. We also communicated the research findings from the case study of Tahamata Incorporation in Kuku, Horowhenua, at the dairy shed site via an expanded climate change art and design exhibition in an art museum in Lower Hutt, Wellington. Through these projects, visuals became valuable tools for Māori communities' engagement in environmental research and the development of adaptation strategies that support the linked well-being of hapū, iwi, lands, and waters.

Such new perspectives, alongside the vision statements created by hapū for their coastal lands, are currently being finalized within the next phase of funded research called "Risk Management Planning for Climate Change Impacts on Māori Coastal Ecosystems and Economies" (20I72019). Again, by co-developing transition action plans that, given local 
conditions, will enable Māori communities throughout Aotearoa New Zealand to assess the risks and benefits of alternative coastal land use, the Kei Uta Collective has envisaged integrative decision-making tools that will empower more coastal Māori landholders to take needed steps toward new environmental stewardship and protections. To this end, our Māori participants are actively investigating the return of pā harakeke, or New Zealand flax (Phormium tenax) plantations, to the riparian banks of the lower reaches of the Kuku Stream to the Ōhau River confluence for a potential sustainable fine fabric industry. The disused dairy shed site may become a harakeke hub for processing fiber. Some coastal hapu are also looking at revitalizing aquaculture opportunities in freshwater fisheries, while others are engaging with innovative architectural solutions to dune lands and river bank erosion on sites along the lower reaches of the Waikawa River.

\section{A Background on Current Climate Change RESEARCH EXPLAINED}

Before expanding further on all these matters, it is important to contextualize the scope of the research platform on which the current climate change research endeavors are based. When I was research leader for the мтм project, my core Māori research team, Aroha Spinks and Moira Poutama, used mātauranga Māori knowledge systems and cultural indicators (as outlined earlier) alongside Western sciences to determine the key ecological and cultural landscape decline issues facing coastal ecosystems. In MTM, we sought answers to how best to enhance and restore the value and resilience of coastal ecosystems and their ecosystem services in order to make a positive contribution to iwi and hapu identity, survival, and welfare in the case study regions (Smith, Spinks, Hoskins, and Poutama 2OII).

We also encouraged related hapū, Māori cultural leaders, and other kaitiaki (environmental guardians) to collaborate with our diverse range of specialists to assess the decline of freshwater quality and to highlight social factors around that decline, build up baseline knowledge, and simultaneously set strategies in place for returning health to reconnected systems. Our teams grounded this work within whakapapa, the genealogical reference systems that revitalized our people's relationship to place, to each other, and to the natural environment. We used hìkoi guided by our kōrero tuku iho, or oral narratives of place, in order to 
increase these connections. MTM investigated intricate and complex environmental problems while enhancing how our related Māori communities might reunite with the natural environment in order to exercise kaitiakitanga in modern times, promote sustainability, and restrengthen hapū identity through a grounded relationship with Papatūānuku (Earth Mother) (Smith 2007).

Respectfully, our Māori team also recognized how our Māori knowledge systems have changed and been adapted over generations due to impacts of colonization or shifts in spiritual belief systems. When reinvigorating customary values, we acknowledged them as fundamental for forming principles and guiding philosophies for culturally based sustainable management strategies that tackle contemporary concerns. Changes can inform new perspectives, so we reapplied Māori values in direct response to the precarious contemporary world we inhabit. Over the мтм research years, we prioritized seven more revitalization opportunities for valued ecosystems. Each project aimed to honor the values listed above and to exercise kaitiakitanga as a socio-environmental ethic that increases holistic human and environmental well-being (Smith 2007).

As part of this background on transformative solutions undertaken over time, the projects engaged hapu and freshwater experts in a wide range of hands-on activities within the case study region, including:

I. Microbial source tracking for Waiwiri Stream and the coastal area at Muhunoa (20IO-20I2);

2. The Ōhau River loop project for assessing the existing state of the river meander, with recommendations and actions to improve the habitat for whitebait fisheries (20I I-20I5);

3. In response to the very poor water quality results for Waiwiri Stream, a larger assessment of fecal contamination in shellfish between Hōkio Stream and Ōtaki Beach (2014);

4. Identification of factors affecting populations of toheroa, a taonga species of shellfish (20I2);

5. Enhancement of coastal wetlands within Māori lands by expanding the reach of kawenata (protective covenants) that linked Te Hākari dune wetland on Tahamata Incorporation farm with Pekapeka Taratoa's and Incorporation of Ransfield's neighboring lands;

6. Revitalization of the entrance to the sensitive Kuku Ôhau estuary with a fenced carpark, a gate to prevent destructive vehicular access, and extensive native planting (2012-present); and 
7. Revitalization of water health and related biodiversity for the revered Lake Waiorongomai, led by Ngā Hapū of Ōtaki (2OI 2-present).

To expand, the first prioritized project included tracking Escherichia coli (E coli) within the Waiwiri Stream from its Lake Waiwiri (Papaitonga) source to the sea. Its poor water quality had severed hapu relationships and inhibited the sourcing of safe foods to eat, whether eels or shellfish. Therefore, based on the unsafe levels of $E$ coli bacteria found in shellfish north and south of the mouth of the Waiwiri stream, this project called on more hapu participants to come together with shellfish scientists and hydroecologists to conduct a larger survey into the sources of fecal contamination for additional shellfish gathering sites along the coast between Hōkio and Ōtaki. For the Ōhau River meander project, we facilitated Horizons Regional Council's installation of a fish-friendly floodgate in the lower reaches of the Ôhau River loop in 2013. The following year, we worked with local Māori shareholders (including whitebaiters), hydroecologists, freshwater ecologists, and other scientists to survey and quantify the spawning areas for inanga (whitebait). Our team also brought together a leading weaver, hapū, senior landscape architecture students, and a soil scientist to expand the potential for a renewed harakeke sustainable fabric industry. We co-convened governance boards from two Māori farms in order to secure more protective covenants with Crown entities that increased protection of contiguous dune wetlands. With Tahamata Incorporation's Māori shareholders' permission, too, our related hapū and Kuku residents-with central, regional, and local government funding support-revitalized the Kuku Ōhau estuary frontage with a beach gate, carpark, and trees to revegetate the 2.2-hectare entrance to the estuary site. The Kei Uta team also helped bring kaumatua together with landscape architecture students' work, hapu landholders, and local and regional government experts to activate the Lake Waiorongomai rehabilitation project, north of Ötaki. The breadth of research and the transformative, hands-on projects highlight the connected interdependencies of the natural ecosystem, Māori economies, the history of whenua (Māori ancestral land), and the people whose knowledge and way of life cannot be separated from it (Smith 2007; Smith and others 20II).

When the first protective covenant for Te Hākari coastal dune wetland revitalization project was signed in 2002 between Crown entities and Tahamata Incorporation farm, coincidental planning and the meeting of requirements had been well underway for a number of Treaty of Waitangi 
claims research projects. While positive relationships had been forged with the Department of Conservation and its Māori subsidiary, Nga Whenua Rahui, over Te Hākari dune wetland's restoration, alongside the efforts of local and regional councils, other historic adverse actions and the failure of Crown agencies to uphold the guarantee of maintaining rangatiratanga of hapu and iwi over inland waterways and lands remain major grievances for which redress is currently being sought. In our case study region and within the wider affiliated tribal area, the Crown legislated for the near wholesale transfer of hapu and iwi lands and their associated waterways into private hands to support the development of pasturelands for farming and ongoing settlement. Once again, this left many hapū and iwi with limited or no access to their treasured waterways and with limited ability to learn and pass on important protocols and knowledge associated with them. The transfer of lands and waterways also left many waterways polluted and unable to support their former abundance of aquatic life. In some cases, historical or ancient waterways have been lost to large-scale deforestation and drainage of wetlands to create new pasturelands. In a dark irony, such new lands exacerbated flooding in an already flood-prone district. The removal of wetlands through drainage schemes also eliminated or significantly reduced the food and other resources within, which had been highly valued by hapū and iwi and formed much of hapu economies. In response to exacerbated flood events, local authorities undertook a number of flood control mechanisms, particularly from the I920s, including further drainage schemes and modifications such as stopbanks, floodway and sluice gate schemes, and the straightening of rivers and tributaries, which continues today (Potter and others 2017).

Despite the severity of these accumulated Crown failures, our hapu have continued to assert rangatiratanga over inland waterways. Today, we give expression to this as kaitiaki for maintaining our freshwater bodies into the future, hence all the collective мтм and climate change, kaupapa Māori, and action research undertaken to date.

\section{The Image as Critical Catalyst for Change}

As a practicing artist, I introduced the commissioning of high-resolution aerial photographs, large-scale mapping via landscape architecture design, and my own painting process as part of this interdisciplinary, collaborative research. Each medium played a critical visual role in synthesizing com- 
plex findings on compounded environmental decline and climate change impacts from colleagues in the natural sciences. Whether this was done via large-scale imaging, aerial photos, maps, or projected drone-camera footage as part of our collective hui, hīkoi, or wānanga with hapū participants, communities of interest, and farm board members or individually via my paintings for exhibition, each visual approach helped bring everyone closer together to identify the issues and strategize solutions going forward.

In producing my own individual responses to ecological decline via the medium of oil paint on stretched linen, in Te Rae \#2, I coalesced Māori concepts and my personal observations of global-local economic tensions and their impacts on nature with the ongoing sorrow I felt for adverse MTM research findings for freshwater flowing through our whenua (figure 2). This artwork exemplifies the concept of "te rae," which refers to the forehead, specifically the zone that sits before the frontal lobe of the brain. This part of the brain allows humans to recognize the future consequences resulting from their current actions. "Te rae" also refers to a headland or landmass overlooking a body of water. This is a recurring visual metaphor throughout the series I painted between 20 I I and

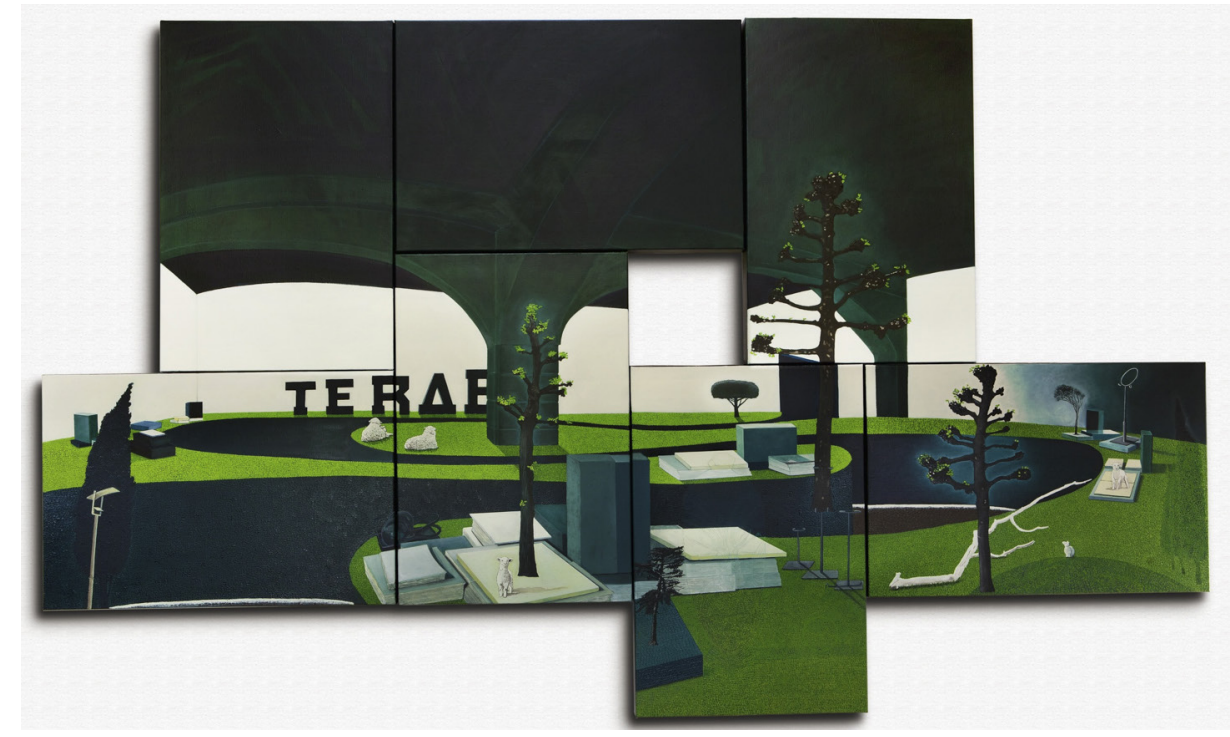

Figure 2 Te Rae \#2, by Huhana Smith. Oil on linen, 20I3, $750 \mathrm{~mm} \times 500 \mathrm{~mm}$ each canvas, 2,500 mm X I,500 mm complete. Photo by Norman Heke. Reproduced with permission. 
20I4. Most importantly, Te Rae \#2 synthesizes my concerns for our grave human and global economic impacts on nature and biodiversity.

My artworks were also influenced by the coincidental development of the Rae ki te Rae Bicultural Design Studio (20II-20I4), which was cocreated by professor Penny Allan from the Victoria University of Wellington Faculty of Architecture and Design and my research company, Te Rangitāwhia Whakatupu Mātauranga, which included Aroha Spinks, Moira Poutama, and myself. Our compelling design studio for senior landscape architecture students studying at the university was ultimately a successful innovation, particularly in terms of its development of research protocols for meaningful and purposeful cultural exchange. We engaged with students on more or less equal terms, which proved to be surprisingly effective. Based on this experience of working with hapu participants, current and future bicultural design studios should take cognizance of the following protocols:

I. Be preceded by an apprenticeship in the culture, its history, cosmology, customs, and language;

2. Be characterized by a fundamental shift in methods;

3. Lead to innovation, greater relevance, and additional opportunities for the creation of new knowledge;

4. Have active Māori participation, as both researchers and respondents;

5. Use both mainstream and Māori tools for analysis;

6. Include Māori values and concepts as a basis for assessing the relevance and potential benefits of the research;

7. Establish and follow a code of ethics;

9. And, most importantly, avoid liberal use of mātauranga Māori in a manner that runs the risk of distorting both its context and its content (Allan and Smith 20I3).

\section{Catalyzing Environmental Projects}

To pause and highlight a crucial moment back in autumn of I996, it was a local group of traditional Māori healers called Te Raukawakawa o Te Ora and other relations from Ôtarere Limited who instigated the first rounds of necessary dialogue around ecosystem decline for freshwater sources in Kuku, which was within (and would become) the main ongoing coastal case study region. From their activities (alongside other environmentally 
like-minded relatives) the opportunity arose to commission a report that combined their initial conversations about the loss of vitality in key waterways with actions that could alleviate these concerns.

Di Lucas of Lucas Associates, a landscape architecture firm based in Christchurch, was the first primary external expert who helped these groups reassert their obligations of kaitiakitanga to promote and maintain indigenous flora and fauna as valued taonga, and to help encourage more hapū members to look after associated fresh waterways or waiora (freshwater) springs for healing practices. The resulting report outlines the first potential major project for restoring life to the nitrified and polluted lower reaches of the Ōhau River (Lucas Associates I998). In addressing the impacts of a council-instigated diversion in 1972-1974 for the Ōhau River, known locally as the "loop," and its adjacent blind creek, Lucas's report clearly delineates the required activities that would ease the problems for this river remnant. The report does not avoid signaling the extent of ecological degeneration, but it frames the concerns in a deliberately user- and information-friendly format. This is to entice participants to restore health to areas rather than to alienate them to the labor-intensive tasks ahead or to de-motivate them over the severity of the decline. The report, Kuku-Ōhau Ecological Situation and Opportunities in the Lower River, Preliminary Notes, carefully describes recommendations and activities that could improve ecological health by drawing on the creative potential and promise derived from a combined environmental and human health perspective.

With this first report in hand, healers and environmental guardians began to overcome their anxiety about the loop's depleted vitality. Upholding responsibilities for treasured species such as inanga became tantamount. Equipped with this information, they concentrated on revitalizing the biocultural relationships between peoples and ecosystems (Smith 2007). By sharing the report widely, the groups helped reassociate hapu and shareholders with the spiritual significance of this river meander site and discouraged local and wider communities' disregard for the region, particularly since it had been used for effluent discharge from the farm's dairy shed and as a local dumping ground for hard rubbish. These actions seemed anathema for such a unique, dynamic, and treasured coast.

Another compelling reason for coming together to heal natural integrity in the ancestral landscape was to alleviate dysfunction experienced between related peoples. As researchers trying to activate solutions to 
our environmental problems, we at times witnessed vehement arguments between hapū members. We recognized that "if pollution, contamination or desecration impacted on the mauri or life vitality of revered places within the natural environment, then this influenced the communities who were reliant on the land, often manifesting in disquiet, disunity or fragmentation amongst peoples" (Smith 2007). Therefore, the Ōhau River loop experience became the founding example on which to build the later hands-on rehabilitation projects for the wider case study region's wetlands, streams, and river systems that connect to the sea listed earlier.

Rolling forward to the enhanced role that landscape architecture and design would play in the overall success of the MTM research, the next climate change project, known as "Adaptation Strategies for Climate Change for Coastal Māori Communities" (2015-20I7), continued to work in earnest with design experts from Victoria University of Wellington. Their studios remained the learning hub from which further collaborations were realized between Māori researchers, hapū participants, professors in landscape architecture, senior 2-D designer students, and other MA students. Our interdisciplinary Kei Uta team also brought additional design and resilience theory, visual technologies, and illustration software on the landscape level to our consideration of the cultural concerns of hapū and the case study region. For example, when hapu representatives came to help evaluate students' work during staged, critical reviews of their developing ideas, they could readily see the real potential of students' well-devised projects to actually help them tackle the issues they faced for their coastal ecosystems.

The overall adaptation strategies project drew substantially on мTM's findings and experiences, its bicultural design studio, and its protocols for engagement. MTM used a combination of different design approaches and other sources, which included archaeoseismology, ecology, and coastal processes and hazards expertise. The landscape architects integrated these with approved cultural knowledge of place and current environmental decline concerns. When each leading expert presented for students attending our Māori-grounded hui and wānanga at marae (Māori principle homes or community centers), their morning talks were followed by students, experts, and hapu specialists walking the same regions in the afternoon. This wānanga and hīkoi approach provided considerable scope for students to imagine a range of sound practical solutions that addressed degradation of critical ecosystems in a region with vulnerable settlement patterns and inappropriate farming practices. As stated earlier, maintain- 
ing Māori values and kaitiaki responsibilities in the face of major coastal changes is a significant challenge because "business as usual" farming is often privileged over strategizing adaptations for change.

Despite these realities, the Kei Uta team aimed to capture the specific risks and opportunities based on projected climate change related impacts for the Ōhau and Waikawa Rivers case study region. Our resulting tool kit of maps was designed to provide holistic scenarios aimed at increasing local Māori shareholder capacity and to help us critically consider which adaptations to climate change might lead to new processes and diversified farming practices. The team also recognized that rural and peri-urban areas' adaptation strategies to sea-level rise should be different from those in cities because of their less intensive forms of coastal development (Smith and others 2017).

In considering water management, the Kei Uta geomorphologist and climate change scientist acknowledged that more extensive flooding and potential salination of groundwater are likely for our coastal communities. They completed GIS analysis using data from soil surveys (including drainage classes), flood mapping, modelling, and LidAR (or Light Detection Ranging, a remote sensing method that uses light in the form of pulsed lasers to measure ranges, or variable distances, to the Earth). This research clearly identified areas of the coastal region that are most vulnerable to sea-level rise and climate change effects. In all this work, and though personal artworks might satisfy my own artist's sensibility to think through the issues faced, the most powerful way we found to share multifaceted climate change research findings for communities was via the exhibitions (Smith and others 20I7).

\section{Exhibitions as Research and Dissemination Methods}

The value of exhibitions as a means of disseminating complex information is evident in the impactful work of curators and museum leaders like Jennifer Newell, Libby Robin, and Kirsten Wehner. They highlight "the moral responsibilities of museums to address climate change, not just by communicating science but also by enabling people already affected by changes to find their own ways of living with global warming" (Newell, Robin, and Wehner 2017). To this end, our team's first two public climate change exhibitions, under the Wai o Papa/Waterlands banner, were held at the Victoria University of Wellington Faculty of Architecture and Design. These exhibitions, displayed in the faculty's front window gal- 
lery, broadcast new knowledge on a range of interdependencies that exist between cultural, economic, ecological, and climate change issues.

The first window gallery exhibition was held from 3I May to I7 June 20I6. It drew together data on geological time, geomorphology, groundwater, and current climate change science. The second exhibition, from 2I June to 30 September 20I6, featured elements of Māori understandings of water and tidal cycles via the maramataka, or Māori lunar calendar. In both exhibitions, the graphics were applied to the glass window. Each image on glass was superimposed over an expansive photographic backdrop of the Kuku Ōhau estuary. The key point of the first exhibition's graphic was to interpret the scientific data on global sea levels through a process of mapping. We aimed to describe the cyclic interdependencies between water and atmospheric dynamics over hundreds and thousands of years. We showed the cycles of sea level in flux over four hundred thousand, ten thousand, and the last thirty years and overlaid these with the influences of El Niño and La Niña, the annual cycle of the tides caused by the earth's orbit around the sun, the monthly influence of the sun and moon's alignment on the tides, and, finally, the diurnal cycle caused by the gravitational pull of the moon as the earth spins on its axis. In representing the map as a field of influences, we recognized the current change in climate as part of a much bigger, more complex, and interdependent system of atmosphere, land, and water (Bryant, Allan, and Smith 20I7).

The second exhibition focused more on historic Ōtaki-based Māori narratives of an esteemed Māori tohunga, or esoteric knowledge leader, Metera Te Ao-Marere. The main point of this lunar calendar graphic was to represent Te Ao-Marere's cycles of time and his responses to rhythms of sea and land. This interpretation appealed to daily Māori rituals brought about by nuanced observations gathered over generations. Both window gallery exhibitions were foregrounded by the illuminated "Seas Will Rise" artwork lightboxes that stood close to the exhibition site on adjacent Vivian Street-a major thoroughfare in central Wellington. Each Wai o Papal Waterlands exhibition proved to be a successful way of sharing complex information from scientific and Māori customary knowledge perspectives (Bryant, Allan, and Smith 20I7). The site-based exhibit by the street also stayed up long after the window gallery exhibitions were taken down. The team was enthused by responses to both exhibitions by the funders, universities, visitors, and passersby. During this time, the Kei Uta Collective also began the process of organizing a larger, site-based exhibition 
planned for Kuku as part of their project's requirements to disseminate more research findings.

It was during a wānanga held at Tukorehe Marae in Kuku on 3 November 2016 that hapu participants anchored the notion of staging more exhibitions with a set of collated vision statements. With elders and environmental guardians at that wānanga, the first protocol they developed was for whanaungatanga ki te whenua, that is, bringing whanau, or families, back to their whenua. Might this mean that whanau could invest in their farms and be able to live on higher lands or adapt to rising tides in welldesigned, sustainable, intergenerational homes? The next vision, building on all the environmental work undertaken to date and keeping the momentum of restoring environmental health well into the future, was about te puawaitanga o te whenua, or ensuring that Māori farms are ecologically and economically viable. It also followed that whakahokia ngā kai o te awa, or returning traditional resource management to waterways where possible, might ensure that kai moana (seafood) from the sea was healthy, that eels and other treasured species like whitebait were replenished into healthy freshwater environments again, and that sustainable harvest protocols were activated again. Similarly, kaitiakitanga mō āpopo was about Māori landholders protecting their Māori farms in order to benefit tomorrow's generations. This vision also related to considerations of an ancestral past whereby tiakitanga o ngā wāhi tapu (protection of sacred grounds) was acknowledged as actively protecting ancestral sites and burial areas as places of great spiritual significance within cultural landscapes. All of these vision statements emphasized the importance of maintaining tikanga Māori or customary protocols of hapū, and with them envisaging their own futures.

With the two window exhibitions garnering support, the third exhibition in the series, called Whakatairangitia: Rere ki Uta, Rere ki Tai, was held in a disused dairy shed complex on Tahamata Incorporation's farm in Kuku, Horowhenua on I I-I 2 March 20 I 7 (figure 3). While only expected to last a weekend, the exhibition stayed up for a full week to meet community demand. The shed complex stands by the Kuku Stream and near an important ancestral site, which was part of a former papakāinga, or nineteenth-century Māori settlement. The papakāinga site also included a burial ground adjacent to the sheds, hence its special nature. The dairy sheds exhibition brought together mātauranga Māori, art, culture, design, and science from both Māori and interdisciplinary perspectives. The event opened that morning with a formal pōwhiri, or welcoming ceremony 
according to Māori custom, for visitors to Tukorehe Marae in Kuku. The exhibition and opening that followed in the afternoon were specifically designed for Māori shareholders of Tahamata Incorporation, Massey University colleagues, the farm's board members, local hapū, other neighboring residents, local and regional government officials, and the funders from Massey University and the Ministry of Business, Innovation and Employment. All other Māori principle investigators from around the country had also been invited. They were leading other Vision Mātauranga climate change projects funded under the Deep South National Science Challenge (Deep South Challenge 2019).

To explain the dairy shed exhibition layout, each well-cleaned and prepared shed was thematically organized. The first and oldest shed in the complex was underpinned by the Mãori concept of whakapapa, the second shed by hìkoi, and the third shed by kōrero tuku iho. These concepts are again derived from a Māori worldview in which whakapapa describes interconnections between all things; hīkoi involves observing knowledge by sensing and feeling places, especially when taking hīkoi journeys across lands and along waterways; and kōrero tuku iho provides the lan-
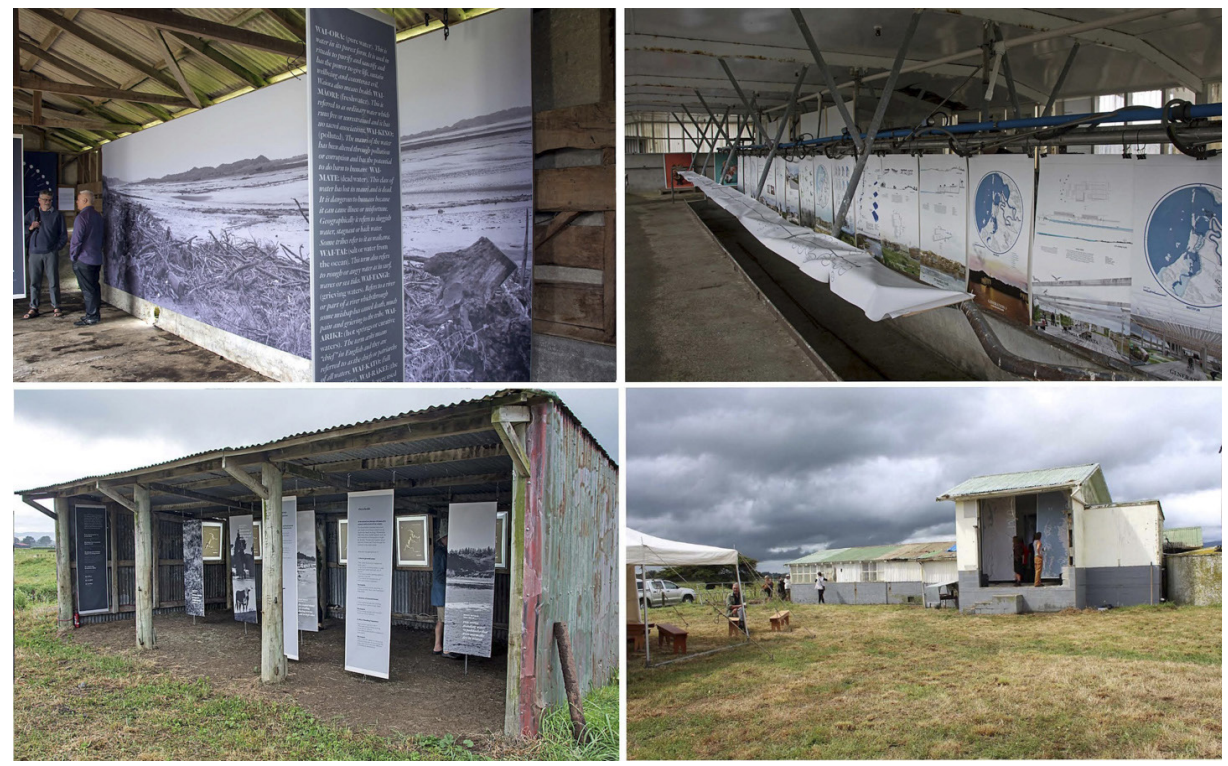

FIgURE 3 Whakapapa, hīkoi, and kōrero tuku iho sheds at Whakatairangitia: Rere ki Uta, Rere ki Tai, Kuku Dairy Sheds exhibition, Kuku, Horowhenua, I I March 20I7. Photo by Martin Manning. Reproduced with permission. 
guage and moments that connect people, things, and places through local knowledge of place. The whakapapa shed housed the significant Māori knowledge pertaining to the ancestral lands on which it stood. It also safeguarded the vision banners determined by hapu. This shed anchored the geological time and maramataka information from the previous window exhibitions (Bryant, Allan, and Smith 2017), all the while dominated by the powerful Kuku Ōhau River estuary image taken by our climate change science expert.

The hikoi shed was about the journey of the research and how researchers, hapū, and students engaged with coastal ecosystem decline. We held around twenty-six hilkoi as part of the MTM research from November 20 IO to March 20I4. It was through this research method that we developed the image as critical catalyst for making change. Hikoi were a very successful part of the landscape architecture students' and our hapu's learning. We continued to use hîkoi in subsequent climate change research to draw new peoples to the experience so they could closely observe, sense, and feel place, all while being grounded by its cultural significance.

Within the hik koi shed, there was a recurring theme in the senior students' designs of how farm activities needed to diversify practice while maintaining agricultural productivity. For example, one student group illustrated this through a proposal on revitalizing pā harakeke that called for reconfiguring paddocks and their use and creating a harakeke processing hub at the disused dairy shed site. The scheme imagined riparian tracts alongside the Kuku Stream planted with harakeke sourced from close wetland fringes. Dairying was to be relocated to higher ground across the river. The potential for diversifying farming with harakeke is well established, for in the late I830s to mid I 85 os, harvesting harakeke from the margins of wetlands and waterways was a practice led by our local hapū of Ngāti Tukorehe. With neighbors Ngāti Wehiwehi and Ngāti Kapumanawawhiti from Kuku and Ōtaki, respectively, our ancestors developed a significant and sustainable industry around harakeke fiber.

Such an attempt to reestablish pā harakeke for a renewed, sustainable industry in fine fabric would have significant environmental benefits, as it would involve cleaning up polluted waters like the Kuku Stream that flows past the disused dairy sheds and into the Ōhau River. Riparian replenishment with harakeke would encourage biodiversity, slow down floodwaters, minimize the effects of erosion and land loss, buffer other areas against sea-level rise, and mitigate coastal impacts of higher or more salinized water tables. A reinvigorated industry would champion the blur- 
ring of boundaries between past, present, and future land and water use practices in economically and environmentally sustainable ways, which also aligns perfectly with the vision statements exacted by hapū.

Another recurring theme in the student work in the Kuku dairy sheds exhibition was the idea that sea-level rise might paradoxically encourage whanau to reinhabit the land in papa kāinga-like clusters of Māori communal housing on higher dunes. In the designs put forward, each unique housing type worked as a way of living in raised small villages at the edge of water bodies. To the audience and shareholders who came to view the Kuku exhibition, these ideas for quality adaptable homes that can adjust to both rising water in wetland areas and placement on high dunes were very attractive.

The hīkoi shed also included a range of artworks. Martin Bryant, as a leading landscape architect, provided a series of drawings that responded to the many hîkoi undertaken during the course of the research. Massey University MA student Kevin Carthwright created large-scale photos of storm surges taken at Kuku Ōhau estuary in 20I6. His images of king tides at full moon backed the large sea-level rise banners designed by the team's 2-D designer, Abdullah Richards. Art photographer Ann Shelton shared works highlighting the significance of harakeke and other native plants as rongoā, or plants with healing properties used by Māori in the past and present. I provided items from my Pā Harakeke: Ideas Towards Healing installation, including two detailed models of the dairy shed complex itself and a bottled karakia (Māori incantation), each of which I placed under a Perspex dome and arranged on a painted trestle table. My contribution also emphasized holistic solutions for enhancing water quality, lands, people, and farm stock, along with aspirations toward a sustainable harakeke fine fabric industry as integral to sustainable farming economies for better futures.

In climate change research like this, there is a very clear relationship between what might happen and what needs to be done. When these adaptation strategies need to happen is much harder to establish, as there is still considerable convincing with evidence to do, particularly for farming governance boards. Thresholds and triggers are indicators of key ecological relationships and are part of both Western science and mātauranga Māori knowledge frameworks. Therefore, the Kei Uta team considered thresholds related to aggradation, flooding, salination, and wetland buffers. The kōrero tuku iho shed embedded the story of environmental thresholds on the farm as stimuli for action. In identifying these thresh- 
olds for the farm, we determined corresponding, coordinated, and realistic actions and highlighted them by hanging "what if" banners, such as "What if you see standing water in paddocks?" or "What if you are seeing coastal erosion?" Placed behind these banners at the back of the shed were corresponding LED lightboxes that displayed the adaptive solutions. For example, the solution for standing water in paddocks was to enhance protection by retreating from wet coastal paddocks or by planting an alternative crop like harakeke that can cope with wet conditions. The multipart solution for coastal erosion was to retire tracts of land and then buffer the coastline with appropriate native grasses, groundcovers, and sedges for coastal driftwood edges; reestablish reeds to low-level shrubs beyond these edges; and return lowland coastal forest species farther inland from the reeds and shrubs buffer.

Coincidentally, the Wai o Papa/Waterlands exhibition was held in Kuku on a weekend of torrential rain, the same weekend that began the wettest period in the history of recorded rainfall in the Horowhenua district. While our coastal lands remain vital economic assets and sources of cultural identity for Māori shareholders, they are vulnerable to climatic extremes including increased rainfall, storm surges, flooding, coastal erosion, and groundwater salination (Manning 20I6).

Also during this research period, Melanie Oliver, senior curator at the Dowse Art Museum in Lower Hutt, Wellington, invited the Kei Uta Collective to consolidate our research findings and art and design outcomes into a final, culturally grounded, museological reiteration of the Whakatairangitia: Rere ki Uta Rere ki Tai exhibition concept. This opportunity featured the Kei Uta Collective's perspectives among those of other artists who were tackling the difficulties of climate change within a contemporary art exhibition titled This Time of Useful Consciousness: Political Ecology Now. The exhibition was held at the Dowse Art Museum from I3 April to 3I July 2017.

Our collective continues to feel strongly that art as critical consciousness or as reflections on the human condition, in (re)creating interactions between the cultural and natural, can demonstrate and respond to the environmental threats of the twenty-first century. Through design, we have shown how communities might adapt to inevitable change, all the while backed by evidence-based findings in technical reports, a range of compelling practical actions, well-mapped toolkits of adaptation strategies, and the impetus to develop more national and international transdisciplinary exhibition opportunities as they emerge from ongoing research. 


\section{Conclusion}

It is now almost twenty-three years since healers first lamented the state of the Ôhau River loop, their inability to source safe freshwater for rituals and healing from waterways and former spring sources, and the decline in treasured whitebait fisheries. Since this airing of concerns, hapū of Ngāti Tukorehe have become renowned for catalyzing significant environmental action via major collaborative efforts, which have also spread, or been aligned with, other iwi and hapū efforts across the wider Ngāti Raukawa ki te Tonga region. Such interconnected agency with other hapu and iwi and with other experts has influenced and encouraged more local and regional communities to become solutions-focused, technologically innovative with design and art, and open to integrating Māori cultural, ecological, environmental, and social factors. All efforts are backed by evidencebased, technical research reports and practical, hands-on restoration of valued coastal ecosystems. Simultaneously, this intensive research has involved examining the historic failures of Crown agencies to protect our inland waterway resources and clearly indicates that there are grounds for redress for the damage exacted on freshwater bodies through the Waitangi Tribunal research claims process.

There is no doubt that this coastal case study region remains a vibrant hub of activities for our hapū researchers, our hapū participants, and a range of other experts who are drawn to the whanau of Kei Uta Collective. We used art and design approaches via the series of Wai o Papal Waterlands exhibitions to bridge Māori culture, climate change and geomorphological sciences. We strengthened localized cultural knowledge of place as the lens through which these climate change and fluvial geomorphology sciences can be viewed. We did this for the sake of expanding our communities' understanding of complex climate change data. In developing design scenarios that encouraged beneficial relationships between culture, settlement form, ecologies, economies, and farming practices, we then revealed them through the exhibitions for both targeted and wider audiences. Our research methods allowed for the dissemination of complex information in accessible ways. The Wai o Papa/Waterlands exhibitions became our essential visual tools for effecting change in the mindsets of our Māori communities.

Currently, as part of phase two of "Risk Management Planning for Climate Change Impacts on Māori Coastal Ecosystems and Economies,” 
we are developing and finalizing integrative decision-making tools that might enable more coastal Māori landholders to assess the risks and benefits associated with alternative coastal land uses and economies through transition action plans and preferred scenarios. All in all, as hapu who have spent many years reconnecting with ecosystems within our natural coastline by physically revitalizing them as ancestral landscapes, we tackle from a strengthened base the precarity of unpredictable climate change and its effects now.

THE CORE MTM MĀORI RESEARCH TEAM HAS WORKED WITH a range of people and entities since 20 Io. The list includes: School of People, Environment and Planning, Massey University; Faculty of Architecture and Design, Victoria University of Wellington; Manaaki te Awanui Trust in Tauranga, with Caine Taiapa as MTM Research Leader Māori for the Tauranga Moana [harbour] case study; Te Reo a Taiao, the Ngāti Raukawa environmental resource unit (Taiao Raukawa) with myself as мTM Research Leader Māori in the Horowhenua coastal case study; Cawthron Institute, based in Nelson (provided coastal and freshwater ecological expertise); WakaDigital Ltd, based in Tauranga (provided information communication and technology expertise for both case studies); Te Rünanga o Raukawa, Ōtaki; Raukawa ki te Tonga Trust (Mandated Iwi Organisation for Fisheries); Ngā Hapū o Ōtaki; coastal farm boards such as Incorporation of Ransfield's and Tahamata Incorporation; Te Iwi o Ngāti Tukorehe Trust; Ngā Kaitiaki o Ngāti Kikopiri; Ngā Kaitiaki o Ngātokowaru; Ngā Hapū o Hìmatangi; Ngā Kaitiaki o Ngāti Kauwhata; Muaūpoko Tribal Authority; Te Iwi o Ngāti Tukorehe Trust, Kuku; Greater Wellington Regional Council, Wellington; Kāpiti Coast District Council, Paraparaumu; Waitohu Stream Care Group, Ōtaki; Royal Forest and Bird Society, Horowhenua; Horowhenua District Council, Levin; Hōkio Progressive Association, Hōkio; Horizons Regional Council, Palmerston North; Department of Conservation, Palmerston North, and local residents and landholders between Hōkio and Ōtaki coastal townships.

\section{References}

Allan, Penny, and Huhana Smith

20I3 Research at the Interface: Bicultural Studio in New Zealand, a Case Study. MAI Journal: A New Zealand Journal of Indigenous Scholarship 2 (2): I33-I49.

Bryant, Martin, Penny Allan, and Huhana Smith

2017 Climate Change Adaptations for Coastal Farms: Bridging Science 
and Mātauranga Māori with Art and Design. In Resilient Edges, a special issue of The Plan Journal 2 (2): 497-5 I 8.

Deep South Challenge

2019 Deep South Challenge: Changing with Our Climate. Project website. https://www.deepsouthchallenge.co.nz [accessed Io June 20I9]

Lucas Associates

I998 Kuku-Ōhau Ecological Situation and Opportunities in the Lower River, Preliminary Notes. Christchurch: Lucas Associates.

Manaaki Taha Moana

2015 Manaaki Taha Moana. Project website. https://www.mtm.ac.nz [accessed Io June 20I9]

Manning, Martin

2016 A Summary of Climate Change Issues for the Horowhenua. Wellington: Deep South Project, sponsored by the National Institute of Water and Atmosphere.

Ministry of Research, Science and Technology

2007 Vision Màtauranga: Unlocking the Innovation Potential of Māori Knowledge, Resources and People. Wellington: Ministry of Research, Science and Technology.

Newell, Jennifer, Libby Robin, and Kirsten Wehner

2017 Curating the Future: Museums, Communities and Climate Change. London: Routledge.

Potter, H, Aroha Spinks, Mike Joy, Mahina-a-rangi Baker, Moira Poutama, and Derrylea Hardy

2017 Porirua ki Manawatū Inland Waterways-Historical Report. Commissioned by Crown Forest Rental Trust for the Porirua ki Manawatū Inquiry. Wellington: Te Rangitāwhia Whakatupu Mātauranga Ltd and Crown Forestry Rental Trust.

Roberts, Mere, Brad Haami, Richard Benton, Terre Satterfield, Melissa L Finucane, Mark Henare, and Manuka Henare

2004 Whakapapa as a Māori Mental Construct: Some Implications for the Debate over Genetic Modification of Organisms. The Contemporary Pacific I6 (I): I-28.

Salmond, Anne

2014 Tears of Rangi: Water, Power, and People in New Zealand. HAU: Journal of Ethnographic Theory 4 (3): 285-309.

Smith, Susan M

2007 Hei Whenua Ora: Hapū and Iwi Approaches for Reinstating Valued Ecosystems within Cultural Landscape. PhD dissertation, Te Pūtahi $\bar{a}$ Toi, Massey University. 
Smith, Huhana, Penny Allan, Martin Bryant, Derrylea Hardy, Martin Manning, Murray Patterson, Moira Poutama, Abdullah Richards, Jane Richardson, and Aroha Spinks

2017 Adaptation Strategies to Address Climate Change Impacts on Coastal Māori Communities in Aotearoa New Zealand: A Case Study of Dairy Farming in the Horowhenua-Kāpiti Coastal Zone. Palmerston North: Massey University.

Smith, Huhana, Aroha Spinks, Tipene Hoskins, and Moira Poutama

20I I State of Ecological/Cultural Landscape Decline of Horowhenua Coastline between Hokio and Waitohu Streams. Manaaki Taha Moana Research Report 2. Palmerston North: Massey University.

van Meijl, Toon

20 I 5 The Waikato River: Changing Properties of a Living Māori Ancestor. Oceania 85 (2): 219-237.

Wagner, John R, and Jerry Jacka

20I8 Island Rivers: Fresh Water and Place in Oceania. Canberra: ANU Press.

Winter, Christine

2017 The Paralysis of Intergenerational Justice: Decolonising Entangled Futures. PhD dissertation, University of Sydney.

\section{Abstract}

Since I996, considerable challenges have faced hapū in terms of ecosystem decline in lands and waterways within southwestern coastal Māori lands from the Horowhenua to Kāpiti regions of Te Ika a Maui/North Island, Aotearoa New Zealand. The rationales for hapù re-enhancing intergenerational connections to their lands have required culturally led, collaborative, innovative, solutionsfocused, and transformative actions to reinstate well-being to areas of cultural and natural value. Beginning with the project "Manaaki Taha Moana: Enhancing Coastal Ecosystems for Iwi and Hapū" (2OIO-2OI5), hapū have collaborated with specialists to cocreate new frameworks for addressing short-term issues and long-term impacts of sea-level rise, leading to the "Adaptation Strategies for Climate Change for Coastal Māori Communities” project (20I 5-20I7). Building on Māori methods such as wānanga, hui, and hīkoi, these approaches have strengthened localized cultural knowledge of place as the lens through which climate change and fluvial geomorphology sciences can be viewed. Developed design scenarios have encouraged beneficial relationships between culture, settlement form, ecologies, economies, and farming practices in order to better pre- 
pare Māori communities for the ecological and socioeconomic impacts of climate change. Art and design have helped bridge Māori culture, sciences, and communities' understanding of complex data within university-based and curated exhibitions. The latest project, "Risk Management Planning for Climate Change Impacts on Māori Coastal Ecosystems and Economies" (20I7-20I9), envisages integrative decision-making tools to enable more coastal Māori landholders to assess the risks and benefits associated with alternative coastal land uses and economies.

KEYWORDS: climate change, mātauranga Māori, whakapapa, hīkoi, kōrero tuku iho, adaptation strategies, transition action plans 